\title{
Hexapanopeus manningi, a new xanthid crab (Crustacea, Decapoda, Xanthidae) from Brazil
}

\author{
Cheruparambil Sankarankutty ${ }^{1,2}$ \\ Alexander Cesar Ferreira ${ }^{1}$
}

\begin{abstract}
A new species of xanthid crab, Hexapanopeus manningi, closely related to $H$. caribbaeus Stimpson, 1871 collected from mangrove areas in the estuaries of Rio Grande do Norte, Brazil is described. This is the sixth species of Hexapanopeus Rathbun, 1898 from Brazil. Distinguishing features of the species are also mentioned to facilitate its separation from closely related species.

KEY WORDS. Crustacea, Decapoda, Xanthidae, Hexapanopeus manningi, new species
\end{abstract}

The new species reported here was collected from the intertidal and sublittoral regions of three estuaries within the State of Rio Grande do Norte, Brazil between March 1996 and June 1999. The species is common in the mangrove area as well as sublittoral region where the substratum is made up of sand and gravel. Hexapanopeus manningi is the sixth species belonging to the genus to be reported from Brazil.

\section{MATERIAL AND METHODS}

The specimens studied here were collected from the intertidal region of a mangrove area near the city of Macau, the sublittoral region of the estuaries of the river Potengi, Natal, estuaries near the cities of Macau, Galinhos and Tibau do Sul. Four different types of dredges were utilized for the collection from the sublittoral region.

Type specimens are deposited in the reference collections of the Museu Nacional Rio de Janeiro (Holotype); National Museum of Natural History, Smithsonian Insitution, Washington, D.C.; Natural History Museum (British Museum), London and the rest at the Department of Oceanography and Limnology, Universidade Federal do Rio Grande do Norte, Natal, Brazil.

Abbreviations used are: (cl) carapace length; (cw) carapace width; (MNRJ) Museu Nacional do Rio de Janeiro; (BMNH) The Natural History Museum, London; (NMNH) National National Museum, Smithsonian Institution, Washington; (DOL) Departamento de Oceanografia e Limnologia, Natal.

1) Departamento de Oceanografia e Limnologia, Universidade Federal do Rio Grande do Norte. 59014-100 Natal, Rio Grande do Norte, Brasil.

2) Bolsista do CNPq. 


\section{Key to Brazilian species of Hexapanopeus (Adapted from Sankarankutty \& Manning, 1997)}

1. Anterolateral teeth 4, fifth minute, almost posterolateral. Apex of gonopod with long, tapering lateral process $\ldots \ldots \ldots \ldots \ldots \ldots \ldots \ldots \ldots \ldots \ldots \ldots \ldots \ldots$

- Anterolateral teeth 5, fifth well developed and lateral. Apex of gonopod blunt,



2. Third anterolateral tooth of carapace spiniform and acute. Distal margin of median



- Third anterolateral tooth of carapace not spiniform and acute. Distal margin of median process of gonopod not spiny . . . . . . . . . manningi

3. Carpus of cheliped not markedly tuberculate. Colour of fixed finger of chela extending proximally and dorsally onto palm . . . . . . . . . . 4

- Carpus of cheliped with about 15 irregularly placed tubercles, Colour of fixed finger of chela barely extending onto palm (Apex of gonopod trilobate) ... - paulensis

4. Edge of front thick and beveled. Apex of gonopod a single rounded lobe, with $2-3$ spines . . . . . . . . . . . . . . . . . 5

- Edge of front not thick or beveled. Apex of gonopod subtriangular, lacking apical

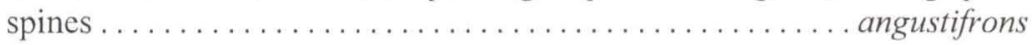

5. Subhepatic region with a large tubercle. Frontal margin without double lines of

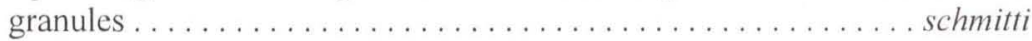

- Subhepatic region without a large tubercle. Frontal margin with double lines of



\section{Hexapanopeus manningi sp.n.}

Fig. 1

Description. Carapace (Fig. 1A) broader than long, sub-quadrate, surface smooth with regions faintly defined; two pairs or rarely one pair of faint transverse carinae on protogastric, a curved carina on epibranchial and in some cases with feeble carina on mesogastric regions; surface naked except for few hairs. Front bilobed, with wide v-shaped median groove, frontal margin straight or weakly concave in larger specimens with outer angle steeply sloped, two distinct deep supraorbital notches separating tooth-like median part; sinuous and beaded infraorbital border with shallow notch near outer angle and tooth-like projection at inner angle. Pterygostomian and subhepatic regions smooth with few hairs. Anterolateral margin distinctly shorter than posterolateral margin; lateral margin with five teeth, four in the anterolateral margin and rudimentary fifth in posterolateral margin; first tooth (outer orbital angle) small with pointed tip separated from second by concave groove; second tooth with convex margin; third tooth widest and almost triangular in shape, its anterior margin almost straight or slightly concave and posterior border curved; fourth tooth sharper, pointed anterolaterally and with concave anterior and nearly straight posterior border; fifth tooth on posterolateral margin represented by indentation, weakly so in smaller specimens. 

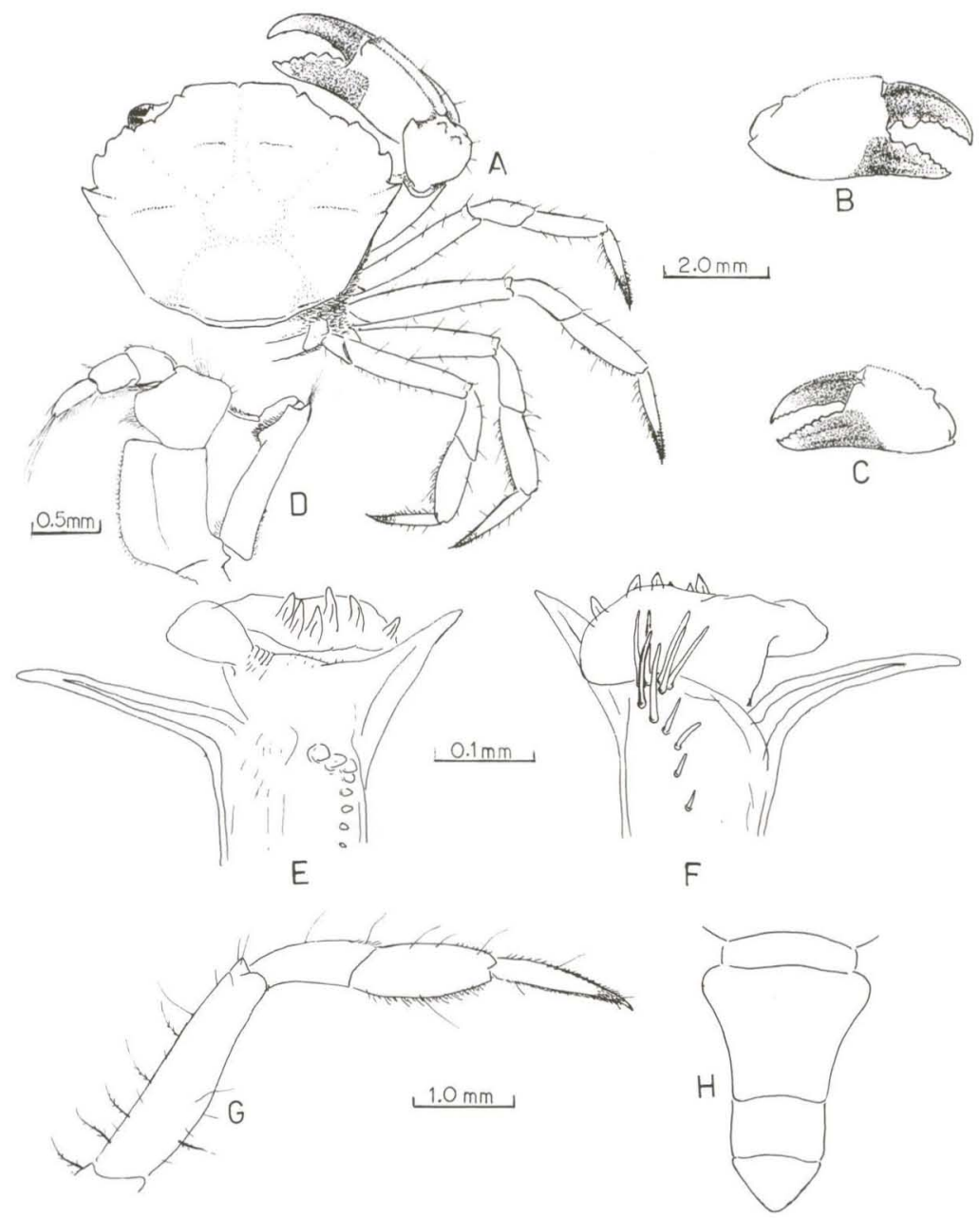

Fig. 1. Hexapanopeus manningi male paratype. (A) Dorsal view of animal; (B) outer view of larger chela; $(C)$ outer view of smaller chela; (D) third maxilliped; $(E)$ ventral view of male pleopod; (F) left male pleopod dorsal view; $(G)$ fourth walking leg; $(H)$ male abdomen.

Chelipeds (Fig. 1B, C) unequal moderately or strongly in male, segments smooth, few hairs distributed sparsely on all segments. Carpus armed with a distinct tooth distally on inner side of larger cheliped, less conspicuous on smaller cheliped, two tubercles or projections on upper surface of larger cheliped but less evident in smaller cheliped and smaller specimens. Propodus robust in larger males with two longitudinal carina on upper surface, outer surface smooth in larger chela especially in males and in smaller chela rugose in some with two longitudinal lines of granules 
on lower half. Fingers pointed and dark with whitish tips, darkened basal part extending to distal part of palm in males and confined to the fingers in females, cutting edge of fixed finger saw-like with conical teeth or with wavy margin, cutting edge of dactylus of larger chela with a large tooth near its base followed by sinuous margin.

Walking legs (Fig. $1 \mathrm{G}$ ) long, segments slender and unarmed but with long bristly setae, more abundant on ventral margin of propodus and dactylus. Second and third legs subequal and longer than first and fourth. Fourth leg normally shortest or subequal to first, dactylus longer than propodus in all legs or slightly shorter.

Third to fifth segments of male abdomen (Fig. 1H) fused; segment 6 and telson much broader than long; tip of telson with rounded tip.

First male pleopod (Fig. 1E, F) slightly bent, with a distinct long tapering subdistal inner spiny process, a tapering pointed process on the opposite side and an expanded hood-like median process lacking spiny border but having three to six short subdistal median spines (Fig. 1E) and several long and thin spines farther behind on dorsal side (Fig. 1F).

Color. Dull greyish green when live.

Holotype. Male: cl $4.7 \mathrm{~mm}$, cw $6.4 \mathrm{~mm}$; deposited in MNRJ (MNRJ 13401), collected from sublittoral region near Galinhos, Rio Grande do Norte.

Paratypes. A male, cl. $4.7 \mathrm{~mm}$, cw $6.4 \mathrm{~mm}$ (USNM No. 260923) and a female, cl. $4.2 \mathrm{~mm}$, cw $5.5 \mathrm{~mm}$ deposited in NMNH (USNM No. 260924); a male, cl 4.7 $\mathrm{mm}$, cw $6.2 \mathrm{~mm}$ deposited in the BMNH (NHM No. 1998 2077); several specimens ranging in size from $\mathrm{cl} 3.0 \mathrm{~mm}$ to $5.2 \mathrm{~mm}$ and $\mathrm{cw} 4.0 \mathrm{~mm}$ to $6.4 \mathrm{~mm}$ with DOL.

Etymology. Named after Dr. Raymond B. Manning, Smithsonian Institution, Washington, U.S.A. in recognition of his outstanding contribution to carcinology.

\section{DISCUSSION}

With the discovery of a sixth species, the species of Hexapanopeus known from the Brazilian waters are: $H$. angustifrons (Benedict \& Rathbun, 1891); $H$. caribbaeus (Stimpson, 1871); H. heblingi Rodrigues \& Loyola e Silva, 1998; H. paulensis Rathbun, 1930; H. schmitti Rathbun, 1930 (COELHO \& RAMOS 1972; CoelHo et al. 1994; Melo 1996) and Hexapanopeus manningi sp.n..

The present species which is relatively common in the mangrove areas in the sublittoral region, has a sympatric distribution with $H$. schmitti though the latter has a wider range occurring also under the stones and oyster beds and underneath coral rocks of the sublittoral and intertidal region of the estuaries and in the open sea area.

This species is remarkably close to $H$. caribbaeus and $H$. beebei Garth in the general morphology having an ill-developed fifth lateral tooth on carapace and presence of a long tapering lateral spine near the distal end of the first gonopod. While the chelae in $H$. caribbaeus and $H$. manningi are coloured they are whitish in H. beebei (GARTH 1961). H. beebei has a wide gaping fingers on the larger cheliped while such gap is not present in $H$. caribbaeus and $H$. manningi. The median process in $H$. beebei is semicircular in shape while it is laterally elongated and oblong in $H$. caribbaeus and $H$. manningi; it also has a long distally pointing and tapering distal process extending well beyond the median lobe. The distin- 
guishing features of $H$. caribbaeus and $H$. manningi are (1) a straight or weakly concave frontal margin in $H$. manningi, while a concave frontal margin in $H$. caribbaeus (RATHBUN 1930, plate 171, figs 4). (2) $3^{\text {rd }}$ lateral tooth of the carapace is not spiniform and acute in $H$. manningi while it is large and spiniform directed anterolaterally in $H$. caribbaeus (RATHBUN 1930, plate 171, fig. 4). (3) the median process of gonopod is armed with short spines all along the border in $H$. caribbaeus (SANKARANKUTTY \& MANNING 1997, fig. 5a, b) while no such spinulation is present in H. manningi. H. beebei (MARTIN \& ABELE 1986, fig. 2D) also lacks spinulation on the distal margin of the median process.

\begin{abstract}
ACKNOWLEDGEMENTS. This study was carried out with the financial support from the Brazilian Petroleum Company (PETROBRAS) - a post-graduate scholarship to A.C. Ferreira and logistic support for the collection. We also thank the National Council for the Development of Science and Technology $(\mathrm{CNPq})$ for its support. Part of this study was carried out at the Natural History Museum (NHM), London during a short visit of the senior author financed by CAPES, Ministry of Education, Brazil and the British Council. Special thanks are also due to Dr. Paul F. Clark of NHM for all the help received during the visit, to Dr. Peter J.F. Davie of Queensland Museum, Australia for useful discussion and to the two anonymous referees for valuable suggestions.
\end{abstract}

\title{
REFERENCES
}

Coelho, P.A. \& M. Ramos. 1972. A constituição e a distribuição de fauna de decapoda do litoral leste da América do Sul entre as latitudes $5^{\circ} \mathrm{N}$ e $39^{\circ} \mathrm{S}$. Trabs. Oceanogr, Univ. Fed. Pernambuco 13: 133-236.

Coelho Filho, P.A.; S.M.A. Coelho \& P.A. Coelho. 1994. Estudos dos Xanthidae (Crustacea Decapoda - Brachyura) da Praia de Piedade, Jabaotão-PE. Rev. Nordest. Zool., Maceió, 1 (1): 125-141.

GARTH, J.S. 1961. Brachygnatha Brachyrhyncha. Non-intertidal brachygnathous crabs from the West coast of tropical America, Part 2. Eastern Pacific Expeditions of the New York Zoological Society, XLV. Zoologica 46 (3): 133-159.

Martin, J.W. \& L.G. Abele. 1986. Notes on male pleopod morphology in the brachyuran carb family Panopeidae Ortmann, 1893, sensu Guinot (1978) (Decapoda). Crustaceana 50 (2): 182-198.

Melo, G.A.S. 1996. Manual de identificação dos Brachyura (caranguejos e siris) do litoral brasileiro. São Paulo, Ed. Plêiade, 603p.

Rathbun, M.J. 1930. The cancroid crabs of America. Bull. U.S. Nat. Mus. 152: XIV+609p.

Rodrigues, M.D. \& J. Loyola E Silva. 1998. Descrição de Hexapanopeus heblingi sp.n. (Crustacea, Decapoda, Brachyura, Xanthidae) do litoral brasileiro. Revta bras. Zool. 15 (1): 261-271.

SAnkarankutty, C. \& R.B. Manning. 1997. Observations on Hexapanopeus schmitti Rathbun from Brazil (Crustacea: Decapoda: Xanthidae). Proc. Biol. Soc. Wash. 110 (2): 249-25.

Recebido em 19.VIII.1999; aceito em 22.VIII.2000. 